\title{
Developing Ethical Leaders: Innovations in Promoting Ethical Decision-making, Using Discretionary Power \& Overcoming Immunity to Moral Integrity
}

\author{
Gail F. Latta \\ Xavier University \\ Emmanuel Clottey \\ Louisiana State University - Shreveport \\ Molly Dugan \\ Xavier University \\ Michael Chikeleze \\ Xavier University
}

This integrative review highlights emerging issues hindering the study and practice of ethical leadership, offering a critical analysis of three fundamental topics: the role of disposition versus situation in ethical decision-making, a leader's use of discretionary power, and the reciprocal relationship between learning and development in maximizing a leader's capacity for ethical leadership. Following her analysis of each of these crucial topics, the first author outlines innovative strategies leaders can implement in their own organizations to remedy each, providing practical advice about: Conducting organizational ethics audits, assessing situational factors influencing leaders' ethical decisions, and overcoming psychosocial immunity to moral integrity.

Keywords: ethical leadership, moral integrity, decision-making, leadership development, ethics audits, situational influence, psychosocial immunity, research agenda

\section{INTRODUCTION}

Ethics is so consequential to human society that it has been the subject matter of philosophers, clerics, educators and developmental scientists for centuries. Scholars in each of these disciplines approach the topic from different perspectives, seeking to answer distinct fundamental questions. This raises the question whether we have been using similar terminology to describe wholly different phenomena. Leadership scholars have attempted to address this lack of conceptual clarity by employing more precise terminology to distinguish the among specific dimensions of ethical leadership: character (Judge, 2001; Sharma, 2002); integrity (Kaiser \& Hogan, 2010 ; Palanski \& Yammarino, 2009); moral judgment (Rest et al., 1999; Thoma \& Dong, 2014); moral potency (Hannah \& Avolio, 2010); virtue (Dahlsgaard, 
Peterson \& Seligman, 2005; Peterson \& Seligman, 2004; Riggio et al., 2010); organizational virtue (Wright \& Goodstein, 2007), as well as differentiating between ethical leadership (Brown \& Trevino, 2006; Langlois et al., 2014; Yukl et al., 2013) and ethical leadership at work (Kalshoven, Hartog \& Hoogh, 2011). While lack of conceptual clarity persists in the study of ethical leadership, interest remains high in understanding how to overcome obstacles to developing leaders capable of demonstrating morale integrity in their decision-making and use of discretionary power in ethically complex situations in organizations and society.

Moral integrity has been incorporated as a core construct in many contemporary theories of leadership, including transformational (Avolio, Bass, \& Jung, 1999), authentic (Novicevic et al., 2006), servant (Liden et al., 2008), spiritual (Fry, 2003) and ethical leadership (Brown \& Trevino, 2006), as well as emerging theories of followership (Gerpott et al., 2019; Lee, 2016). Trait theories of leadership suggest moral judgment is rooted in dispositional (Zaccaro, 2007) or socioanalytic dynamics (Judge, Piccolo \& Kosalka, 2009). Brown and Trevino's conceptual review of the foundations of ethical leadership identifies both trait and situational factors as antecedents. Kalshoven, Hartog and De Hoogh (2011) include integrity among the seven behavioral dimensions ethical leaders exhibit, along with: people orientation, fairness, power sharing, concern for sustainability, ethical guidance, and role clarification.

Leadership professionals' desire to develop ethical leadership capacity exceeds extant theoretical and empirical knowledge in the field. Antecedent to knowing how, are questions regarding even if it is possible for a leader's capacity for ethical leadership to be enhanced. Despite investing billions annually on leadership development initiatives, organizations have failed to deliver long-term change in leadership behavior, skills and habits (Kivland \& King, 2015; McNulty, 2017). Reasons identified include the generic nature of training, lack of opportunities to practice the application of new skills, and failure to consider the impact of organizational culture (Beer, Finnstrom \& Schrader, 2016; Gurdjian, Halbeisen \& Lane, 2014). As a result, investments in leadership development fall short of promoting ethical conduct and decision-making. Before investing more in these efforts, it is important for social scientists to untangle the unresolved issues concerning the nature of ethical decision-making, and the consequence of these decisions for ethical leadership.

A combination of innovative practice and robust research is needed to fill this gap. Recognition of the consequences of unethical decision-making by leaders amplifies the urgency to form collaborative partnerships between leadership scholars and practitioners to advance our understanding of the challenges and consequences of enacting ethical leadership. Leadership professionals can contribute by adopting innovative practices designed to promote moral integrity and accountability in their organizations, allowing researchers to expand their study of fundamental questions relating to the nature of ethical leadership and its development. Working together, the leadership profession can equip leaders with practices grounded in knowledge rather than speculation. Given that the purpose of social research is to describe, not engineer reality, pursuing a collaborative, practice-driven research agenda will guard against equipping practitioners with unverified prescriptive directives, rather than fact-based principles of ethical leadership grounded in solid empirical evidence.

Three problems in particular, derived from recent research and theory regarding the nature of ethical leadership, call for increased attention among scholars and practitioners. For each of the conceptual issues identified, this article will propose a path forward in which practitioners can help overcome the current limits of research by implementing innovative strategies to address the development of ethical leaders, followers, organizations and societies:

1. Clarify the dispositional versus situational components of ethical decision-making by helping to identify situational moderators that shape ethical leadership in practice.

2. Account for the effects of discretionary power and self-interest on ethical leadership by conducting organizational ethics audits to hold leaders and organizations accountable.

3. Reinforce the reciprocal contributions of learning and development to enhancing ethical leadership by adopting strategies that help leaders overcome their immunity to ethical leadership. 
An interdisciplinary agenda for promoting ethical leadership will include clarifying the methodologies and strategies for enhancing moral reasoning, promoting discretion in the use of power, and removing barriers to ethical conduct in the environments in with leaders and followers interact.

After describing the current state of scholarship respecting each of these areas of ethical leadership practice, an innovative strategy for advancing both practice and research will be proposed to address the concerns highlighted. The objective in each instance is to promote ethical leadership practice by proposing innovative techniques that speak to emerging issues derived from the current literature on ethical leadership. Articulating a path forward for researchers and practitioners will serve to clarify and extend the current state of theory and practice in the field. These discussions will highlight the relevance of conducting collaborative research to: 1) identify the contextual moderators of ethical leadership, 2) improve the practice of conducting organizational ethics audits, and 3) remove the psychosocial barriers that create immunity to developing ethical leadership capacity in leaders and the organizations they serve.

\section{DISPOSITIONAL VS. SITUATIONAL ROOTS OF ETHICAL LEADERSHIP}

Initial efforts to understand the nature of ethical leadership centered around the development of normative instruments for assessing a range of leader behaviors (Brown, Trevino \& Harrison, 2005; Kalshoven et al., 2011; Yukl et al. 2013). These instruments rely upon followers' 360-feedback regarding presumed behavioral indicators of ethical leadership. However, none of these instruments actually characterize the nature of ethical decision-making in the context of ethical dilemmas leaders typically encounter. More recently, researchers have begun conducting studies designed to probe the thought processes underlying ethical decision-making (Chikeleze \& Baehrend, 2017; Latta \& Dugan, 2019). These studies rely upon self-report instruments designed to discern the ethical principles leaders employ in making ethical decisions. By focusing on the antecedents of ethical decision-making, these researchers seek to elucidate the cognitive dynamics that inform ethical leadership behavior

Studies of ethical decision-making have been conducted from contrasting theoretical perspectives. Adopting a trait-perspective, Chikeleze \& Baehrend (2017) sought to identify stable preferences among individuals making ethical decisions. Subsequently, Latta and Dugan (2019) reported evidence individuals shift their approach to resolving ethical dilemmas depending upon the situation. Working independently, these teams have pursued research agendas documenting how individuals make ethical decisions in relation to hypothetical scenarios requiring ethical judgments. Approached from two different theoretical perspectives, results of these studies point to different conclusions about the nature of ethical decision-making (Latta et al., 2019).

\section{Trait/Dispositional Perspective}

Research grounded in a trait perspective has sought to determine whether leaders exhibit consistency with respect to the ethical principles reflected in how they report responding to a range of ethical dilemmas (Northouse, 2019). The assumption is that, when faced with an ethical dilemma, the moral reasoning a leader goes through is primarily grounded in a predisposition toward of one of six ethical orientations: 1) duty 2) utilitarianism 3) virtue 4) caring 5) egoism and 6) justice. The Ethical Leadership Style Questionnaire (ELSQ) was developed to assess individual preferences for each of these ethical orientations. The ELSQ is a 45-question, forced-choice, self-report instrument that requires respondents to select one of 6 response options that best describes how they would likely respond to a variety of hypothetical ethical dilemmas.

The ELSQ does not measure ethical behavior or reasoning per se; instead, it focuses on the leader's "ethical leadership style." (Chikeleze \& Baehrend, 2017). By asking respondents to select what they consider to be the best solution to a range of ethical dilemmas, based on what concerns them the most in each scenario, the ELSQ purports to identify respondents' primary ethical orientation. Individual selections are tallied to determine the aggregate score for each orientations, with the highest score representing the primary area of concern considered when making a decision, and the lowest score reflecting to area of least concern. For example, a person scoring highest on justice and lowest on 
utilitarianism would put more emphasis on doing what is fair than, on what benefits the most people when making a decision.

Data from two empirical studies found that when faced with making a decision about an ethical dilemma, over $90 \%$ of respondents demonstrated a preference toward a primary ethical leadership orientation on the ELSQ (Chikeleze \& Baehrend, 2017). Researchers have suggested that by comparing the relative aggregate scores for each ethical orientation assessed, the ELSQ can be used to afford leaders insight into their native inclinations in resolving ethical dilemmas. Of course the suggestion there may be a trait-based component to how leaders approach ethical decision-making does not deny the possibility of situational variability. Rather proponents of this perspective suggest awareness of a preference for one ethical orientation over another may help leaders make better ethical choices by encouraging them look at ethical dilemmas from alternative perspectives. Such awareness could remind leaders to consider the merits of alternative ethical orientations in a given situation, rather than relying solely on dispositional preference.

\section{Situational Perspective}

Another independent line of research has produced evidence of a natural tendency toward situational variability in ethical decision making, rather than a dispositional favorability toward one orientation or another (Dugan, 2008; Latta \& Dugan, 2019). These researchers examined ethical decision-making among undergraduate students using five hypothetical scenarios to elicit narrative responses to range of ethical dilemmas typical college students face. Participants were asked to read each scenario and describe, "What would you do?" and "Why would you do this?" (Dugan, 2018, 206). Responses were analyzed for evidence of six ethical principles scholars have identified to be commonly employed by the general population (Johnson, 2018): Kant's categorical imperative, utilitarianism, justice as fairness, altruism, pragmatism, and virtue ethics (Latta \& Dugan, 2019). In addition, participants rated the degree to which they considered each ethical principle in their response to each scenario on a 7-point Likert scale from "not considered in response" to "considered a major factor in response". Qualitative and quantitative results were compared to provide a more complete picture of the principles underlying participants' ethical decision-making within and across scenarios.

Results of this mixed methods study found significant between-scenario effects, suggesting participants varied their decision-making strategies when responding to different ethical scenarios. Moreover, participants' individual responses typically reflected more than one ethical principle, rather than reliance on one predominant orientation. Finally, statistically significant within-scenario effects for each ethical principle, indicated participants were more likely, as a group, to apply the same ethical principles to a given scenario. A consistent pattern of variation in ethical decision-making was employed by participants, indicating that rather than adopt a preference for one ethical principle across all scenarios, participants were more likely to shift their ethical orientation based on the situation (Latta \& Dugan, 2019). Taken together, these results provide strong evidence that when their choices are unconstrained, individuals employ varied decision-making strategies that reflect sensitivity to situational context.

\section{The Interactionist Perspective: Accounting for Contextual Moderators of Ethical Leadership}

The predominant focus of scholars seeking to understand the ethical behavior of leaders and followers to has so far been on assessing others' perceptions and self-assessments of individual differences. As in the study of other psychosocial constructs, this bias toward researching dispositional attributes reflects the human tendency to commit the fundamental attribution error, ascribing observed behavior more to stable, internal characteristics than to variable, external factors (Funder, 2001). This tendency to attribute leaders' behavior to personal attributes may be heighted by "motivated preferences and biases in the ways that people see the world and cope in the world" (Higgins \& Scholer, 2008, p. 183). That is, to the extent we expect to see leaders command the circumstances around us, we default to attributing aspects of the situation to their behavior, rather than seeing their behavior as determined by the situation.

By contrast, Funder (2008) notes, regarding the study of contextual moderators of human behavior generally, "the research literature concerning the effects of situations is much less organized than that 
concerning the effects of dispositions....the situational variables examined in published research are almost completely ad hoc" (p. 571). The methodological challenge of differentiating between dispositional and situational variables is the same in research as it is in everyday life: High demand situations can easily be misinterpreted as dispositional, therefore, dispositional effects can only be determined in low-demand situations (Higgins \& Scholer, 2008). Put simply, we see more native predisposition when choices are not arbitrarily restricted by circumstances. Thus the unexpected (ad hoc) finding of situational variability in ethical reasoning reported by Dugan (2018) suggests that when choices are unconstrained (i.e. not forced), leaders routinely utilize a broader range of ethical perspectives in deciding how to respond to the moral dilemmas they encounter in everyday life. By contrast, the forcedchoice format of the ELSQ, which provides comparatively greater constraint than the open-ended format of the Dugan assessment instrument, may mask a natural propensity toward situational variability in the application of ethical perspectives. Until more systematic research is conducted to determine the exact amount of variance in ethical decision-making accounted for separately by situational vs. dispositional attributes, practitioners may consider the Dugan (2018) results more reflective of how leaders actually make ethical decisions in their natural work environments.

At the same time, it important to acknowledge the potential interaction of situational and dispositional attributes in ethical decision-making, and scrutiny of the research paradigms previously employed may yield clues to the relevant interactions that deserve further study. Thus, the amount of situational constraint imposed by their work environment may be one of many factors that moderate the dispositional preferences leaders exhibit in practice. In pursuing this interactionist approach, however, it is important to recognize that determining the differential effects of dispositional and situational factors is not a zero sum game (Funder, 2001). That is, the proportion of variance in ethical leadership behavior accounted for by individual differences (dispositions) does not reduce the variance accounted for by situational variables, and vice versus. Moreover, because both individual preferences and situational context may independently affect leaders' behavior, Funder (2008) argues researchers and practitioners need to account for the triad of interactions among "persons, situations, and behaviors, in which any element of the triad can be conceptualized in terms of the other two" (p. 577). Thus, a leader's preference for how to approach ethical decision-making may influence their behavior in ways that determine the sorts of situations in which they find themselves encountering ethical dilemmas. This 3-way interaction most closely resembles the complex leadership contexts in which ethical decision-making ordinarily occurs.

Yet the lack of attention to situational moderators in determining leader's ethical behavior may reflect the inherent difficulty of deciphering which of many contextual variables are potentially consequential, a challenge that is not unique to the study of ethical leadership. But to state the obvious, ethical decisionmaking does not occur in a vacuum. And the fact that recent empirical evidence suggests contextual variables play an even greater role in determining the ethical principles actors apply across a variety of circumstances (Latta \& Dugan, 2019) dictates that leadership scholars and practitioners work together to address this problem.

Leadership professionals who seek to understand ethical leadership would benefit from developing an instrument to identify and assess relevant contextual factors that contribute to leaders' ethical decisionmaking and behavior. Such an assessment instrument would assist in identifying the relevant contextual factors that contribute to ethical leadership. Recent efforts to develop the "situational Q-sort" (Wagerman $\&$ Funder, 2006), for assessing the influence of contextual moderators on unspecified behavior, holds promise as a prototype for identifying what aspect of situations may be significant for resolving ethical problems in organizations. One can imagine the utility of developing a specialized assessment tool to aid leadership professionals in assessing the relative contribution of situational factors to ethical decisionmaking. Investing more attention in the identification and assessment of contextual moderators affecting leaders' ethical decision-making and moral behavior could promote greater understanding of the challenges and pitfalls that frequently befall leaders and followers who strive to uphold standards of integrity in organizational and societal contexts. 


\section{DISCRETIONARY POWER \& ETHICAL LEADERSHIP}

Power is frequently discussed in the context of ethical leadership, particularly as it relates to a leader's self-interest (Price, 2008). Power is not equally distributed in society; leaders tend to be allocated greater amounts of power than others by their followers (Burns, 1978). The discretion leaders exercise in making decisions about how to utilize the power allocated to them has recently been discussed as having relevance for ethical leadership (Chikeleze, Latta, \& Johnson, 2018). Discretion is "the freedom to decide what should be done in a particular situation" (Dictionary.com) or "the quality of having or showing discernment or good judgment" (Merriam-webster.com). The power bases that underlie leaders' decisionmaking give leaders authority to act or not to act in given situations (French \& Raven, 1956), but how they exercise that power is often discretionary and a matter of judgment. Together with the disposition and contextual variables discussed previously, discretionary power has emerged as a critical factor in determining leader's capacity for ethical leadership.

Ethical leaders are perceived to have a responsibility to utilize the power invested in them to promote ends that serve a greater good over their self-interested objectives (Price, 2008). Leaders are allowed and expected to use their discretion in decision-making because society cannot legislate or prescribe everything by policy. There are grey areas in life where a policy or legislation may not entirely cover. For these reasons society expects leaders and those in authority to exercise their discretion judiciously in the decision-making process. This expectation is contingent on that fact that leaders are responsible for promoting shared values despite relying upon their own personality and experiences (Rosenau, 2004). The higher a leader is in the chain of command in an organization, the higher the level of their discretionary power. Yet leaders are not disinterested actors in the societal roles they embody, and their exercise of power may sometimes be used to promote dark intentions (Hollis, 2007; Judge et al., 2009; Johnson, 2018). Thus unrestrained power may be harmful to both the organization and society (Espedal, 2007).

Because of the potential negative consequences of unconstrained power, Chikeleze, Latta, \& Johnson (2018) assert ethical leadership requires the exercise of "discretionary power." The five sources of power leadership scholars typically recognize are: legitimate, reward, coercive, expert, and referent (French \& Raven, 1956; Lunenburg, 2012). A leader may possess all five sources of power but how they use each is informed by their own discretion. Discretionary power is not an additional source of power, but refers to latitude leaders are granted to exercise judgement in how to exercise any sources of power they are granted by their followers. Discretionary judgment determines the extent to which a leader's exercise of power is guided by self- vs. others-interests, which may in turn dictate whether he or she is perceived to be an ethical leader (Price, 2008).

Leaders in diverse organizations and industries routinely employ discretion in choosing between alternative priorities and competing needs or interests, in addressing issues and solving problems. While ethical decision-making is not synonymous with the exercise of discretionary power, discretion may be a critical factor in resolving ethically complex organizational challenges. Yet little research has been conducted to identify the factors that influence leaders' use of discretionary power. Studying the dynamics that influence leaders' exercise of discretionary power could provide a context for gaining insight into the complexity of ethical leadership. Results of such research could benefit the leadership practitioners and scholars in organizational studies, as well as the broader society.

\section{Discretionary Power in Practice}

The concept of discretionary power derives from the justice system (Rosenberg, 1971), where it has been studied more extensively than in any other sphere of society. Often referred to as judicial discretion, the use of discretionary power is considered a fundamental characteristic of the American legal system (Murphy, 1991). Law enforcement officers, District Attorneys (DAs) and judges all exercise discretionary power to varying degrees. Law Enforcement officers use discretion in determining who to arrest, and what offences to charge (Cureton, 2000; Smith, Visher, \& Davidson, 1984). District Attorneys exercise discretion in deciding whether to prosecute a case or not. Judges have a wide discretionary latitude once a 
case goes to trial (Higgins \& Rubin, 1980). A judge can decide what evidence can be admitted, how and what to instruct the jury (in a jury trial), what objections to accept from both the prosecution and defense, and when an accused is convicted, the judge often has discretion in determining what sentence to impose (custodial or non-custodial).

The executive branch of government also has broad discretionary power to influence many aspects of citizen's everyday lives. Generally, political leaders are expected to exercise their power in a fair and ethical manner, but doing so may reflect priorities established at the leader's discretion. Priority setting is an area in which leaders are often given wide latitude to exercise discretionary power in both private and public organizations. Profits and politics can play a role in setting these priorities, but ultimately it is discretionary power that determines how the priorities are enacted. Decisions leaders make about how to allocate scarce resources, such as where to site municipal services, can determine which communities or geographical locations derive the greatest benefits.

Another manifestation of leaders' exercise of discretionary power is reflected in the personnel decisions that determine the racial/ethnic and gender composition of an organization. Employers have the discretion to determine who gets hired, what benefits employees receive, what their working conditions will be, and which employees will be promoted. Discretionary power may be used to guard against homosocial reproduction, a phenomenon that results when employers only recruit applicants who look like them (based on gender, race, ethnicity, or other biased criteria) (Northouse, 2019). Homosocial reproduction results in organizations being dominated by individuals who confirm to a narrow set of criteria (Kanter, 1977; Murphy \& McIntyre, 2007, Grosvold, 2011), and is pervasive in many private and public organizations including academic institutions (Dressel, Hartfield, \& Gooley, 1994). Discretionary power can be used by leaders to cultivate an inclusive environment by recruiting and promoting employees from diverse backgrounds, narrowing or eliminating gender and racial pay disparities, and balancing competing needs or interests in choosing between alternative approaches to addressing an issue or solving a problem.

\section{Beyond Discretionary Power: Conducting Organizational Ethics Audits}

If a leader's capacity for discretion is critical to ethical decision-making, then understanding discretionary judgement is important because it may be a factor that differentiates one leader from another (Rosenau, 2004). Regardless of the approach to leadership a leader adopts, how they exercise discretionary power may be a distinguishing characteristic of the ethical leader. Yet despite the ubiquity of discretionary power in leadership practice, there is a paucity of research dedicated to it. Research to examine how and when leaders exercise discretionary power, as well as to assess the antecedents and consequences that surround it, could lead to the development of theoretical frameworks that explicate the implications of leader discretion for the practice of ethical leadership.

Given that discretionary judgment appears to be a critical factor in understanding ethical leadership, to the extent power and decision-making are distributed in $21^{\text {st }}$ century organizations (Bolden, 2011; Spillane, 2006), it is important to decipher the dynamics of discretionary power throughout the organizational hierarchy. Besides the influence of their own example, what safeguards can leaders put in place to remind employees throughout the organization of their shared responsibility to uphold institutional values and principles in exercising the discretionary power delegated to them? At the organizational level, conducting an ethics audit is one strategy for aligning employee behavior with established ethical standards. "Ethics audits ensure that the behaviors an organization espouses in its code of conduct and policies and procedures exist in practice and that behavior forbidden in these documents does not occur." (Krell, 2010, pg. 1).

"An ethics audit is a comparison between actual employee behavior and the guidance for employee behavior provided in policies and procedures" (Krell, 2010. p 1). .Reamer (2001) asserts, "a comprehensive ethics audit should assess the extent to which... agencies have practices, procedures, and policies in place to protect clients, identify ethics-related risks, and prevent ethic complaints and ethicsrelated litigation (p. 5). In a presentation to the Society of Corporate Compliance and Ethics, Weber (2008) likened conducting an ethics audit to getting an annual physical, for the purpose of assessing the 
health of an organization's ethics or compliance culture, work climate, policies, training, and enforcement mechanisms, including the existence of an ethics officer, sanctions, rewards, reporting mechanisms, and performance appraisal systems. Weber asserts it is essential for organizations to designate someone at the top of the organization "to coordinate, oversee and enforce the ethics or compliance program" (pg. 15).

Although the practice of conducting an ethics audit is not new, it is vastly underutilized. The practice has been more widely advocated among social services (Reamer, 2001) and nonprofit organizations (National Council of Nonprofits, 2011), although an uptick reportedly occurred in the corporate world in the wake of the passing of the 2002 Sarbanes-Oxley Act on corporate responsibility (Krell, 2010; Weber, 2008). Weber (2010) recommends organizations conduct ethics audits annually, while the National Council of Nonprofits (2011) suggests in some organizations a comprehensive ethics audit every 3-5 years may be sufficient. Reamer (2001) attributes the prevalent use of ethics audits in human service agencies to the "need to ensure that staff are knowledgeable about prevailing ethical standards in order to protect clients and prevent ethics complaints and lawsuits (p. 4). Ethics audits may also prove useful as part of an organizational self-assessment for professional accreditation, "provid[ing] administrators with a very practical, structured, and organized way to assess key issues. Completion of the audit demonstrates administrators' earnest attempt to review and assess important ethical issues (Reamer, 2001, p. 4).

As with financial audits, the purpose of an ethics audit is to ensure compliance across the organization with norms that reflect institutional codes of conduct on a wide range of issues, and to ensure corrections are made where ever departures from acceptable practice are found (Krell, 2010). However, unlike financial audits, which rely largely on archival data, an ethics audit requires the collection and analysis of an extensive amount of qualitative data in the form of self-report, narrative testimony (Reamer, 2001).

Reliable assessment methods and instrumentation are essential for obtaining meaningful results (Weber, 2008). Given the sensitive nature of conducting an inquiry into compliance with ethical standards, and the intense social pressure on employees to present themselves as being in compliance, the probability of bias in self-reported data is high. For this reason, ethics audits rely in part on the anonymous reporting of conscientious co-workers who witness behavior that is out of compliance with espoused standards and norms (Weber, 2008).

Normative instruments may also be used to assess an organization's or work group's ethical work climate. One such instrument by Victor \& Cullen (1988) identifies five types of ethical work environment: instrumental, caring, independence, rules and procedures, law and professional codes. Each type of work climate differentiates among self-, other-, or principled-emphasis with an individual, organizational or societal focus. Reamer (2001) advocates the use of multiple methods of data collection, each targeting specific ethics-related issues identified for assessment:

For example, staff may examine the agency's clients' rights and informed consent forms. In addition, staff may interview or administer questionnaires to 'key informants' in the agency about such matters as the extent and content of ethics-related training that they have receive or provide, specific ethical issues that need attention, and ways to address compelling ethical issues (p. 37).

In the end, however, it is unclear what consequences result for organizations that do not live up to ethical standards of practice, even when those standards are governed by external codes of professional ethics. As Reamer (2001) notes, conducting an ethics audit "is only the first step. Practitioners... who invest the time and energy to audit their ethical compliance should do so only if they have the commitment to correct errors, improve on less than adequate practices, and modify policies and procedures that are lacking" (p. viii). Krell (2010) emphasizes the importance of "disciplin[ing] ethics violations in complete accord with policies and procedures and the code of conduct every time" an infraction or deviation from prescribed norms is brought to light (p. 1).

To prepare organizational leaders for providing such follow-up, Reamer (2001) advocates the results of an ethics audit be assessed by a cross-functional review team and each issue assigned to one of four risk categories ranging from "no risk" to "high risk", with the latter representing "practices [that] are 
seriously flawed; significant modifications are necessary to minimize risk" (p. 38). Placing deficiencies and infractions identified through an ethics audit into ratings categories serves as a signal to leaders and other members of an organization regarding the degree of urgency appropriate for addressing each one.

While ethics audits provide a technique for assessing the degree to which leaders and employees comply with established ethical standards, the practice has not yet become normative practice. An opportunity exists for leadership professionals to further develop and explore the utility of extending the practice of conducting ethics audits, using various methodologies, in a variety of new organizational contexts. As long as conducting and reporting the results of an ethics audit remains voluntary, however, and the consequences self-determined, this technique is unlikely to have a significant impact on ethical leadership. Applied research is needed to address deficiencies identified in the current form and practice of conducting ethics audits, and to assess their potential for enhancing ethical leadership and holding leaders accountable.

\section{RECIPROCAL PROCESSES OF LEARNING \& DEVELOPMENT}

The emerging debate about whether ethical decision-making is determined by dispositional or situational factors, and concern over the sometimes dubious use of discretionary power, raise questions about how, and even if, it is possible to develop ethical leadership capacity among leaders. Confusion about the independent contributions of educational and developmental approaches to enhancing ethical leadership capacity continues to muddle the rhetoric and practice of leadership professionals. Promoting greater understanding of the fundamental distinction and reciprocal relationship between learning and development has potential to improve the efficacy of efforts to enhance the capacity for ethical decisionmaking and practice among practitioners.

While learning deepens the knowledge-base that informs leaders' ethical decision-making, development enhances the sense-making processes that govern the behavioral application of that knowledge in specific circumstances (Hoare, 2011). The knowledge gained through learning is inevitably filtered through the developmental lens of a leader. Thus developmental deficiencies sometimes limit the impact of learning, while developmental gains often create the opportunity for new learning. Similarly lack of knowledge can curtail development, while the acquisition of new knowledge sometimes triggers developmental gains. Until this reciprocal relationship between learning and leadership is embraced, leadership professionals will continue to talk past each other when it comes to understanding and advancing methods of promoting ethical leadership.

\section{Learning}

Sometimes leaders make bad decisions, engage in unethical behaviors, or treat followers in immoral ways because they lack knowledge of what constitutes sound ethical behavior or possess underdeveloped skills of moral reasoning. These matters fall in the purview of educators. Leadership education introduces leaders to alternative philosophical foundations (Dion, 2012; Rosen, 1993), ethical decision-making strategies (Johnson, 2018), and the complex contingencies and consequences that accompany the application of these principles and guidelines in practice (Ciulla, 2014). As an applied skill, ethical leadership can be enhanced through experiential learning that exposes practitioners to case studies and simulations that provide real-time feedback (Mitchell, 2019). Leadership educators should strive to develop engaging virtual educational systems that provide safe environments for practicing ethical problem-solving capabilities without harming others.

\section{Development}

Learning is a necessary but not sufficient remedy for unethical leadership, because in application, the knowledge acquired through learning gets filtered through the lens of a leader's developmental maturation. Maturation is a developmental process that results from self-directed, internally-focused, progressive and qualitative change in the way an individual processes and makes sense of information (Moshman, 2003). As such, developmental maturation cannot be affected by an external agent; it can only 
emanate from within. So development is more individualized than learning, and while the progression of developmental change is generally the same for every individual, the pace of change is different. Maturation also differs from learning in being characterized by developmental plateaus, rather than continuous change. Where along a developmental continuum each individual plateaus and for how long are also highly individualized (Kegan, 1982). The amount of time an individual spends at each plateau may have little to do with the quality of their transition to the next developmental stage.

Development occurs along multiple dimensions simultaneously, each of which may terminate at different points along a continuum. The nature of what triggers movement from one developmental plateau to the next is still unclear, although developmental psychologists agree development takes place out of need, not desire. Human beings do not will their development on the basis of volition; rather, development occurs when it does out of necessity. That necessity emerges from the challenge of navigating increasingly complex environments and circumstances that cannot be interpreted without shifting one's internal meaning making schema (Kegan, 1982). Development informs the sense-making processes by which individuals impose meaning on events they witness and experience in the world, and these meaning making processes are deeply rooted in the existential needs of the actor (Kegan, 1982). Developmental psychologists infer that development is hard work, requiring a tremendous amount of internal energy (Moshman, 2003). Therefore as long as existing methods of interpreting life's experiences result in outcomes an individual finds satisfactory, they experience little internal impetus to develop. But when internal disruption, or a sense of discomfort, renders an individual disquieted, it triggers the internal work required to dissemble an existing world view, so a new, more viable sense-making schema can be constructed. This is the essence of maturational development.

Before development can occur, an individual's consciousness of their own existential needs must shift, and these shifts cannot be affected through educational processes alone. Therefore, development requires a different set of tools (McCauley \& Van Velsor, 2010), strategies (Day, Harrison \& Halpin, 2009), and models (Latta, 2019), than learning. Leadership educators who master these developmental techniques can create circumstances that increase the likelihood of triggering developmental maturation among individuals willing to do the inner work necessary to achieve developmental gains. Both learning and development must occur for individuals to progress to higher levels of understanding and development with respect to ethical leadership. Because these processes are governed by reciprocal psychological dynamics, advances in one may trigger advances in the other (Hoare, 2011). The contributions of both are essential for promoting deeper understanding of the foundations of ethical leadership.

\section{Beyond Learning \& Development: Exploring 'Immunity' to Moral Integrity}

Leaders view the ethical dilemmas that arise in their organizations through a set of implicit commitments embedded in their current developmental lens (Kegan, 1982). The fact that individuals, including those in positions of leadership, do not always choose actions that reflect the highest ethical standards, suggests human beings may possess some psychosocial "immunity" to moral integrity - an internal resistance to seeing and doing what is right despite what a given situation requires. In other words, ethical leadership may be hard, not just because ethical decision-making is complex, but because leaders lack the developmental capacity to see and make sense of the ethical issues they face in their leadership roles, and then to consistently choose actions that align with their ethical decisions. Inevitably, the ethical dilemmas organizations encounter are filtered through the developmental lenses of the people entrusted with leadership responsibility in those organizations and societal institutions (Kegan, 1994). How leaders conceptualize and respond to those ethical dilemmas is as much a function of their developmental capacity as their knowledge of the circumstances.

This notion of "immunity to ethical leadership" is akin to the "immunity to change" that characterizes the inherent difficulties of affecting lasting reforms in human and organizational behavior. First described by Kegan \& Lahey (2009) the idea of psychosocial immunity stems from the embedded assumptions underlying meaning making processes in humans that fuel our "tendency to adopt inaccurate beliefs based on selective observations, false assumptions, and misguided conclusions" (p. 187). Immunity processes 
have been shown to mitigate against affecting change in both individuals and within organizational systems (Latta, 2015).

Extending the concept of immunity to ethical leadership represents a potential path for untangling the complex, multifaceted realities that ensnare leaders and their followers in morally dubious patterns of behavior and unethical decision-making. Leaders view the ethical dilemmas that arise in their organizations through a set of impact commitments embedded in their current developmental lens (Kegan, 1982). Therefore, the ethical decisions leaders reach are constrained by the limits of their development. As leaders develop, they cycle through a series of commitments to social integration and individual differentiation (Kegan, 1982). As they do, leaders gain capacity to conceptualize and consider the multiple contingencies and stakeholders affected by solutions they put forward for resolving ethical dilemmas in the organizations they serve.

Kegan \& Lahey (2009) have proposed an analytical strategy to help leaders uncover and examine these underlying commitments that may be holding them back from being able to see and commit to change initiatives that take into consideration the wellbeing of all stakeholders. Adapting this analytical strategy to help leaders examine the sometimes competing commitments underlying complex ethical dilemmas may provide a productive avenue for advancing leaders' developmental capacity for making and enacting sound ethical decisions. Uncovering the hidden competing commitments that propel leaders toward outcomes that appear inevitable on the basis of explicit commitments and unexamined or unquestioned underlying assumptions could free these individuals and the organizations they lead to embrace more virtuous paths.

\section{FUTURE CONSIDERATION \& IMPLICATIONS}

Researchers cite many factors as potentially contributing to unethical leadership practices: Leaders may lack moral imagination (Johnson, 1994), ethical efficacy or skill, or possess unhealthy motivations such as hubris, greed or prejudice (Johnson, 2018). Followers may contribute through collusion, conformity, or failure to prevent ethical misdeeds (Kellerman, 2005; Thoroughgood et al., 2012). Contextual pressures may induce both leaders and followers to seek advantage through unscrupulous means (Barendsen \& Gardner, 2009; Kellerman, 2005). Implement the strategies outlined in this paper, and studying their effectiveness in addressing all forms of ethical leadership failure, could provide insight into the nature of ethical decision-making, the influence of intrinsic and situational factors, the exercise of discretionary judgment, and the potential for leaders to overcome immunity to ethical leadership.

The existence of contradictory evidence regarding the causes and consequences of ethical leadership reminds us of the importance of not drawing conclusions on the basis of a limited range of leadership practices or a single line of research. Developing an integrated perspective on ethical decision-making that takes into account both intrinsic preferences and situational variability, as well as factors that influence the exercise of discretionary power, is essential to informing the future of leadership development. If pursued, the research agenda outlined here could: 1) disentangle contradictory results from previous studies on ethical decision-making; 2) identify contextual factors that affect ethical decision-making and account for the interaction of dispositional and situational variables; 3) clarify the role of leaders' moral judgement in the exercise of discretionary power; and 4) advance theory and practice regarding the reciprocal contributions of learning and development to overcoming leaders immunity to ethical leadership.

Pursuing these innovations in practice and new lines of research will provide a foundation of practicebased evidence for advancing more effective approaches to combatting unethical leadership dynamics and developing ethical leaders, followers and organizations. Important decisions within the purview of leaders' discretion could be informed by a sound body of empirical knowledge about the foundations of ethical decision-making and the consequences of ethical behavior, rather than speculative prescriptions from potentially biased, motivated actors. By revealing the extent to which ethical decision-making is malleable, leadership practitioners and scholars can help inform the appropriate use of educational and 
developmental interventions to promote sound ethical decision-making and discretionary judgment among leaders and followers in organizations and societal institutions.

\section{REFERENCES}

Avolio, B. J., Bass, B. M., \& Jung, D. I. (1999) Re-examining the components of transformational and transactional leadership using the Multifactor Leadership Questionnaire. Journal of Occupational and Organizational Psychology, 72, 441-462.

Barendsen L., \& Gardner H. (2009) The three elements of good leadership in rapidly changing times. In Eurich J., Brink A. (Eds.), Leadership in sozialen Organisationen. VS Verlag für Sozialwissenschaften. Springer.

Beer, M., Finnstrom, M., \& Schrader, D. (2016, October). Why leadership training fails - and what to do about it. Harvard Business Review, pp. 50-57.

Bolden, R. (2011). Distributed leadership in organizations: A review of theory and research. International Journal of Management Reviews, 13, 251-269.

Brown, M. E., \& Trevino, L.K. (2006). Ethical leadership: A review and future directions. Leadership Quarterly, 17, 595-616.

Brown, M. E., \& Trevino, L. K., \& Harrison, D. A. (2005). Ethical leadership: A social learning perspective for construct development and testing. Organizational Behavior and Human Decision Processes, 97, 117-134.

Burns, G. M. (1978). Leadership. New York: Harper Torchbook.

Chikeleze, M., \& Baehrend, W. (2017). Ethical Leadership Style and Its Impact on Decision-Making. Journal of Leadership Studies, 11(1), 45-47. doi:10.1002/jls.21523

Chikeleze, M., Latta, G., \& Johnson, I. (2018, October 27). Leadership and Discretionary Power: The Impact on Progress and Prosperity. Presented at: International Leadership Association Global Conference, West Palm Beach, FL.

Ciulla, J. B. (2014). Ethics, the heart of leadership (3rd ed.). Santa Barbara, CA: ABC-CLIO.

Cureton, S. R. (2000). Justifiable Arrests or Discretionary Justice: Predictors of Racial Arrest Differentials. Journal of Black Studies, 30, 703-719.

Dahlgaard, K., Peterson, C., \& Seligman, M. E. P. (2005). Shared virtue: The convergence of valued human strengths across culture and history. Review of General Psychology, 9(3), 203-213.

Day, D. V., Harrison, M. M., \& Halpin, S. M. (2009). An integrative approach to leader development. New York, NY: Routledge.

Dion, M. (2012). Are ethical theories relevant for ethical leadership? Leadership \& Organization Development Journal, 33(1), 4-24.

Dressel, P., Hartfield, B. W., \& Gooley, R. L. (1994). The dynamics of homosocial reproduction in academic institutions. American University Journal of Gender, Social Policy \& the Law, 2(1), 3762.

Eisenbeiss, S. A. (2012). Re-thinking ethical leadership: An interdisciplinary integrative approach. Leadership Quarterly, 23, 791-808.

Espedal, B. (2007). Why rules rather than discretion: When the leadership intends to transform a desired policy into reality. Journal of Organizational Change Management, 20, 95-108. doi.org/10.1108/09534810710715306.

Funder, D. C. (2001). Accuracy in personality judgment: Research and theory concerning an obvious question. In Roberts, B. W. \& Hogan, R. (Eds.), Personality Psychology in the Workplace (pp.121-139). Washington, D.C.: American Psychological Association.

Funder, D. C. (2008). Persons, situations, and person-situation interactions. In O. P. John, R.W. Robins, \& L. A. Pervin, Handbook of Personality: Theory and Research (3rd ed., pp. 568-580). Guilford Press.

Fry, L. W. (2003). Toward a theory of spiritual leadership. Leadership Quarterly, 14, 693-728.

84 Journal of Leadership, Accountability and Ethics Vol. 17(2) 2020 
Grosvold, J. (2011). Where Are All the Women? Institutional Context and the Prevalence of Women on the Corporate Board of Directors. Business \& Society, 50(3) 531-555.

Gurdjian, P., Halbeisen, T., \& Lane, K. (2014, January). Why leadership-development programs fail. McKinsey Quarterly. Retrieved from www.mckinsey.com/featured-insights/leadership.

Hannah, S. T., \& Avolio, B. J. (2010). Moral potency: Building the capacity of character-based leadership. Consulting Psychology Journal: Practice and Research, 62(4), 291-310.

Higgins, R. S., \& Rubin, P. H. (1980, January). Judicial Discretion. The Journal of Legal Studies, 9(1), 129-138.

Higgins, E. T. M., \& Scholer, A. A. (2008). When is personality revealed? A motivated cognition approach. In O. P. John, R.W. Robins, \& L. A. Pervin, Handbook of Personality: Theory and Research (3rd ed., pp. 182-207). Guilford Press.

Hoare, C. (2011). The Oxford Handbook of Reciprocal Adult Development and Learning ( ${ }^{\text {nd }}$ ed). Oxford University Press.

Johnson, C. E. (2018). Meeting the ethical challenges of leadership: Casting light or shadow (6th ed.). Los Angeles, CA: Sage.

Johnson, M. (1994). Moral imagination: Implications of cognitive science for ethics. University of Chicago Press.

Judge, W. Q. (2001). Is a leader's character culture-bound of culture-free? An empirical comparison of the character traits of American and Taiwanese CEOs. Journal of Leadership \& Organizational Studies, 8(2), 63-78.

Judge, T. A., Piccolo, R. F., \& Kosalka, T. (2009). The bright and dark sides of leader traits: A review and theoretical extension of the leader trait paradigm. Leadership Quarterly, 855-875.

Kaiser, R. B., \& Hogan, R. (2010). How to (and how not to) assess the integrity of managers. Consulting Psychology Journal: Practice and Research, 62(4), 216-234.

Kalshoven, K., Den Hartog, D.N., \& De Hoogh, A. H. (2011). Ethical leadership at work questionnaire (ELW): Development and validation of a multidimensional measure. Leadership Quarterly, 5169.

Kanter, R. M. (1977). Men and women of the corporation. New York: Basic Books.

Kegan, R. (1982). The evolving self: Problem and progress in human development. Cambridge, MA: Harvard Business Press.

Kegan, R. (1994). In over our heads: The mental demands of modern life. Cambridge, MA: Harvard Business Press.

Kegan, R., \& Lahey, L. L (2009). Immunity to change. Boston, MA: Harvard Business Press.

Kellerman, B. (2005). How bad leadership happens. Leader to Leader, 35, 41-46.

Kivland, C., \& King, N. (2015). Six reasons why leadership training fails: A research review. Leadership Excellence Essentials presented by HR.com, 5-8.

Krell, E. (2010). How to conduct an ethics audit. HR Magazine. Society for Human Resource Management. Retrieved from www.shrm.org/hr-today/news/hr-magazine

Langlois, L., Lapointe, C, Valois, P., \& de Leeuw, A. (2014). Development and validation of the ethical leadership questionnaire. Journal of Educational Administration, 52(3), 310-331.

Latta, G. F. (2015). Modeling the cultural dynamics of resistance and facilitation: Interaction effects in the OC3 model of organizational change. Journal of Organizational Change Management, 28(6), 1013-1037.

Latta, G. F. (2019). Models of leadership development: A conceptual framework linking theory to strategic practice. International Journal of Human Resources Development and Management, 19(4), 367-390.

Latta, G. F., Chikeleze, M., Dugan, M., \& Shandersky, C. (2019, October 27). Differing Perspectives on Ethical Leadership: Empirical \& Theoretical Advances. Presented at: International Leadership Association (ILA) Global Conference, Ottawa, Canada.

Latta, G. F., \& Dugan, M. (2019). Comparing ethical decision-making among undergraduates: The impact of institutional values. Journal of Higher Education Theory and Practice, 19, 56-77. 
Liden, R. C., Wayne, S. J., Zhao, H., \& Henderson, D. (2008). Servant leadership: Development of a multidimensional measure and multi-level assessment. Leadership Quarterly, 19, 161-177.

Lunenburg, F. C. (2012). Power and Leadership: An Influence Process. International Journal of Management, Business, and Administration, 15(1), 1-9.

McCauley, C. D., \& Van Velsor, E. (Eds.). Handbook of Leadership Development (3rd ed.). Jossey-Bass.

McNulty, E. J. (2017). Leadership development's epic fail. MIT Sloan Management Review, 58, 73-80.

Moshman, D. (2003). Developmental change in adulthood. In J. Demick \& C. Andreoletti, (Eds.), Handbook of Adult Development (pp. 43-61). New York: Springer.

Murphy, J. C. (1991). Eroding the Myth of Discretionary Justice in Family Law: The Child Support Experiment. North Carolina Law Review, 70(1), 209-242.

Murphy, S. A., \& McIntyre, M. L. (2007). Board of director performance: A group dynamics perspective. Corporate Governance, 7(2), 209-224.

National Council of Nonprofits (2011). Conducting an ethics audit at your nonprofit. Washington, D.C. Retrieved from www.councilofnonprofits.org.

Northouse, P.G. (2019). Leadership, Theory and Practice (8th Edition). Thousand Oaks, CA: SAGE Publications.

Novicevic, M. M., Harvey, M. G., Ronald, M., \& Brown-Radford, J. A. (2006). Authentic Leadership: A Historical Perspective. Journal of Leadership \& Organizational Studies, 13, $64-76$.

Palanski, M. E., \& Yammarino, F. J. (2009). Integrity and leadership: A multi-level conceptual framework. Leadership Quarterly, 20, 405-420.

Peterson, C., \& Seligman, M.E. P. (2004). Character Strengths and Virtues: A Handbook and classification. Oxford University Press: American Psychological Association.

Reamer, R. G. (2001). The Social Work Ethics Audit: A Risk Management Tool. Washington, D.C.: National Association of Social Workers.

Rest, J. R., Narvaez, D., Thoma, S. J., \& Bebeau, M. J. (1999). DIT2: Devising and testing a revised instrument of moral judgment. Journal of Educational Psychology, 91(4), 644-659.

Riggio, R. E., Zhu, W., Reina, C., \& Maroosis, J.A. (2010). Virtue-based measurement of ethical leadership: The Leadership virtues questionnaire. Consulting Psychology Journal: Practice and Research, 62(4), 235-250.

Rosen, B. (1993). Ethical Theory: Strategies and Concepts. Mountain View, CA: Mayfield.

Rosenau, J. (2004). Followership and Discretion: Assessing the Dynamics of Modern Leadership. Harvard International Review, 26(3), 14-17.

Rosenberg, M. (1971). Judicial Discretion of the Trial Court, Viewed from Above. Syracuse Law Review, $22(3), 635,663$.

Sharma, S. (2002). Character competence of the corporation. Journal of Human Values, 8(2), 107-118.

Smith, D. A., Visher, C. A., \& Davidson, L. A. (1984). Equity and Discretionary Justice: The Influence of Race on Police Arrest Decisions. The Journal of Criminal Law \& Criminology, 75, 234-249.

Soltes, E. (2017). Why it's so hard to train someone to make an ethical decision. Harvard Business Review Digital Articles, 2-4.

Spillane, J. P. (2006). Distributed Leadership. San Francisco, CA: Jossey-Bass.

Thoma, S. J., \& Dong, Y. (2014). The defining issues test of moral judgment development. Behavioral Development Bulletin, 19(3), 55-61.

Thoroughgood, C. N., Padilla, A., Hunter, S. T., \& Tate, B. W. (2012). The susceptible circle: A taxonomy of followers associated with destructive leadership. Leadership Quarterly, 23, 897-917.

Wagerman, S. A., \& Funder, D. C. (2006). The Riverside Situational Q-Sort. Paper presented at Society for Personality and Social Psychology, Palm Springs, CA.

Weber, J. (2008). An annual ethics check-up: Conducting an ethics audit of your organization. Paper presented at the 7th Annual Compliance \& Ethics Institute sponsored by the Society of Corporate Compliance and Ethics, September 14-17, Chicago, IL.

Wright, T. A., \& Goodstein, J. (2007). Character is not 'dead' in management research: A Review of individual character and organizational-level virtue. Journal of Management, 33(6), 928-958. 
Yukl, G., Mahsud, R., Hassan, S., \& Prussia, G. E. (2013). An improved measure of ethical leadership. Journal of Leadership \& Organizational Studies, 20, 38-48.

Zaccaro, S. J. (2007). Trait-based perspectives of leadership. American Psychologist, 62, 6-16. 